\title{
Linseed (Linum usitatissimum L.) genetic resources for climate change intervention and its future breeding
}

\author{
Vikender Kaur $^{1 *}$, Rashmi Yadav ${ }^{1}$ and D.P. Wankhede ${ }^{2}$ \\ ${ }^{1}$ Germplasm Evaluation Division, ICAR-National Bureau of Plant Genetic Resources, New Delhi- 110012, INDIA \\ ${ }^{2}$ Division of Genomic Resources, ICAR-National Bureau of Plant Genetic Resources, New Delhi- 110012, INDIA \\ *Corresponding author. E-mail: Vikender.Kaur@icar.gov.in
}

Received: September 12, 2016; Revised received: February 3, 2017; Accepted: May 15, 2017

\begin{abstract}
Linseed or flax (Linum usitatissimum L.), a multiple purpose crop valued for its seed oil, fibre, probiotic and nutraceutical properties, is adapted to different environments and agro-ecologies. Modern breeding techniques using only limited number of selected varieties have resulted in a loss of specific alleles and thus, reduction in total genetic diversity relevant to climate-smart agriculture. However, well-curated collections of landraces, wild linseed accessions and other Linum species exist in the gene banks and are important sources of new alleles. This review is primarily focused on the studies of genetic diversity of linseed species and evaluation related to tolerance to abiotic and biotic stress factors that could be useful for improving linseed through future promising breeding programs in addition to briefly discussing different morphotypes and nutraceutical importance. Wide diversity in linseed germplasm indicates a considerable potential for improving this crop for both agronomic and quality traits required for developing climate-resilience tailored to specific environments. Recent release of the flax genome sequence coupled with wide range of genomic and analytical tools in public domain has furthered understanding of molecular mechanisms for detailed study of the genes underlying flax adaptation to stress and diversity in commercially important accessions. Important climate related traits and their constituent genes are presented and key developments for the future highlighted emphasizing the urgent need to increase the use of genetically diverse germplasm to meet the emerging challenges in agricultural production and to conserve valuable genetic resources for the future.
\end{abstract}

Keywords: Climate change, Genebank, Genetic resources, Germplasm characterization, Linseed

\section{INTRODUCTION}

Linseed (Linum usitatissimum L.) is an important crop produced for natural textile fibre (linen) or oil for industrial application as well as culinary purpose. Recently the market has evolved around linseed as a functional food laden with health promoting and nutraceutical properties further highlighting its importance and increased demand. The total world production of linseed reached approximately 2.56 million tons in the year 2014, with Canada (34\%), the Russian Federation (15\%), and China (13\%) being the main producers (FAOSTAT, 2016). India is the sixth largest producer in the world with contribution to global linseed area and production $13 \%$ and $5.5 \%$, respectively. However, the average national productivity (403 kg/ ha) is far below the world average $(851 \mathrm{~kg} / \mathrm{ha})$ because of its cultivation in marginal and sub-marginal areas, rain-fed soils, sensitivity to fungal diseases, lack of seed of improved varieties, meager or no application of fertilizers and it's sowing in utera cultivation by resource poor farmers.

In near future, climate change may put strong pressure on breeding community to develop cultivars which can adapt to changing eco-climatic conditions. Access to genetic diversity is essential and prerequisite for improvement as well as adaptation of any crop to changing environment or market needs and the crucial role of germplasm in this regard has been well recognized. Gene bank collections are sources of diverse germplasm collections such as landraces, wild relatives, commercial, obsolete and elite varieties, pure and breeding lines, mutants, polyploids, and hybrids. In world germplasm collections, there are 46,513 linseed/flax accessions reported (with perhaps 10,000 15,000 unique accessions), of which L. bienne (the wild progenitor of cultivated flax) is rarely represented (279 accessions only) in genebanks (Diederichsen, 2007). The National Bureau of Plant Genetic Resources (NBPGR), India is involved in collection, evaluation, conservation, documentation and scientific studies to identify donor germplasm for different traits, has $\simeq 2900$ linseed accessions under its long term storage facility. Three main germplasm resources available to plant breeders are commercial varieties, landraces (primitive cultivars), and a range of wild relatives and weedy races. Linseed germplasm is also represented by cultivars, landraces, wild relatives and other wild ancestral species which breeders can exploit to improve cultivars for future climatic adaptations (Heslop- 
Harrison and Schwarzacher, 2012; Diederichsen and $\mathrm{Fu}, 2008$ ). Early linseed breeding and comprehensive agro-botanic analyses of variation (Vavilov, 1951; Dillman, 1953) revealed the importance of germplasm collections in $19^{\text {th }}$ century. More information on germplasm diversity has been generated over time by studies of Vavilovian collections (Kutuzova, 1998). Further, the use of landraces for fibre flax breeding was described by Zhuchenko and Rozhmina (2000). Such studies have proven to be useful tools for efficiently preserving and using flax germplasm collections (Diederichsen, 2007; Diederichsen and Fu, 2008; Diederichsen et al., 2013). These primary evaluations of flax germplasm collections were followed by numerous secondary evaluations for different characters related to tolerance to biotic and abiotic stress factors (Brutch, 2002; Zhuchenko and Rozhmina, 2000) with recent focus of germplasm screening on monogenic traits, such as disease resistances (Rashid, 2003). Thus, wide diversity available in linseed germplasm collections coupled with characterization and evaluation data is a potential source worth utilization in breeding for improved traits.

History of domestication and morphotypes: Linseed is an annual, self-pollinated and only cultivated species under the genus Linum which is believed to be originated in either the Middle East or Indian regions and spread throughout Asia and Europe, and later into the New World (Green et al., 2008; Soto-Cerda et al., 2013). The domestication of flax was also observed on the Indian subcontinent near the Mediterranean Sea and this region is known to have high biological diversity of genus Linum (Allaby et al., 2005; Fu, 2011). Cultivated species (Linum usitatissimum) arose from a single domestication event from L. bienne, involving selection for annual habit, non-shattering of capsules and more efficient self-fertilization (Fu, 2011). However, there are also other species in the genus Linum which are of vital and emerging interest to linseed researchers, although they belong to the secondary, or even the tertiary, genepool (Kutuzova, 1998). Some of these species are ornamental and their utilization may increase in future e.g. blue and occasional white flowers are frequent in the different species of the $L$. perenne and L. narbonense; yellow flowers characterizing the L. flavum group and red flowered L. grandiflorum are often used as ornamental plants. Divergent selection applied over thousands of years has resulted in fiber (taller and less branched) and linseed types (shorter, more branched, larger seeded) which are the same species but differ considerably in morphology, anatomy, physiology and agronomic performance (Diederichsen and Ulrich, 2009). Fiber flax is currently grown in the cool-temperate regions of China, the Russian Federation and Western Europe while linseed cultivars are grown in Canada, India, China, the United States and Argentina (Green et al., 2008).
Currently the oil-type is fifth largest oil crop and the fibre type is the third largest textile fibre crop in the world (Ottai et al., 2011), although with a markable lower production than the major oil crops (Brassica, soybean and palm) or other fibres (cotton and jute).

A multipotential crop: Linseed provides raw materials for seed oil, stem fibre, paper, wax, nutraceutical and food processing industries. The flax fibre is a valuable raw material for linen clothing, the straw and short fibre for thread, rope and other packaging materials; cigarette paper, currency notes (Cullis, 2011), while the seed oil has been used in production of paints, inks, varnish and quality linoleum flooring because of its unique drying properties (Kurt and Bozkurt, 2006). In addition, linseed varieties with oils suitable for culinary use are also available (Hosseinian et al., 2004). Now a days, these two basic types of uses are supplemented by using of common flax as a functional food (Bassett et al., 2009). Consumption of ground seeds adds nutritional benefits because flax seeds are also a rich source of lignans, compounds that have anticancer properties (Westcott and Muir, 2003). Its oil, characterized by a high concentration of omega $\square 3$ alpha linolenic acid (55-57\%) is used in antihypercholesterolemic drugs for cardiovascular diseases (Simopoulos, 2000). As a rich source of soluble fibre, linseed mucilage constitutes an excellent alternative to inulin (polysaccharide with prebiotic effects isolated from chicory root) exclusively required for the food processing industry (Diederichsen et al., 2006). Recently, there has been a growing interest in the probiotic properties of linseed and its beneficial effects on coronary heart disease, neurological and hormonal disorders (Huang and Ziboh, 2001; Simopoulos, 2002), colon tumor (Dwivedi et al., 2005), breast cancer (Chen et al., 2006) and atherosclerosis (Wang et al., 2005). Keeping in view of increasing demand of linseed due to numerous health benefits, there is consistent need to increase genetic seed yield potential as well as its development into a truly multi-purpose crop.

Value of germplasm for important genes and underlying traits under climate change: Evaluations of flax germplasm collections for disease resistance (Kutuzova, 1998; Zhuchenko and Rozhmina, 2000; Rashid, 2003; Singh, 2004) or adaptation to dry and warm regions (Diederichsen et al., 2006b) deliver information facilitating the use of germplasm collections. Limited success was reported in initial attempts to grow flax in saline-alkaline soil to avoid competition for land with other food crops. Using different strategies, flax breeders have made great efforts to develop a salt tolerant flax cultivar (McHughen, 1987; El-Beltagi, 2008). One of the main factors limiting yield of flax is physiological drought in many regions of the world (Gupta, 2007). This situation, predicted to be the result of global climatic changes, significantly 
Table 1. Recent advances detailing important genes and underlying traits in linseed.

\begin{tabular}{|c|c|c|}
\hline Trait & Description of upregulated/down regulated genes & References \\
\hline $\begin{array}{l}\text { Drought toler- } \\
\text { ance }\end{array}$ & $\begin{array}{l}\text { LEA genes coding for late embryogenesis abundant protein LEA5, dehy- } \\
\text { drin, brassinosteroid-regulated protein BRU1 precursor, calmodulin-binding } \\
\text { heat-shock protein genes, genes encoding cytochrome P } 450 \text { family proteins, } \\
\text { AP2/ERF domain containing transcription factor, brassinosteroid insensitive } \\
\text { 1-associated receptor kinase } 1 \text {, and histone h2b }\end{array}$ & Dash et al., 2014 \\
\hline Fibre quality & $\begin{array}{l}\text { Cell wall related genes (cellulose synthase catalytic subunit c1532) involved } \\
\text { in cellulose biosynthesis, genes involved in secondary cell wall hemicellu- } \\
\text { lose synthesis, phenylpropanoid/lignin biosynthesis, gene (xyloglucan endo- } \\
\text { transglycosylase c5939) involved in cell wall expansion, sucrose partition- } \\
\text { ing and gene (fasciclin-like AGP } 2 \text { - c51183) that has previously been asso- } \\
\text { ciated with both flax fibre formation and G-fibre formation in tree reaction } \\
\text { wood }\end{array}$ & $\begin{array}{l}\text { Roach and Deyholos, 2007; } \\
\text { 2008; Fenart et al., 2010; } \\
\text { Gorshkova et al., } 2010\end{array}$ \\
\hline $\begin{array}{l}\text { Saline and } \\
\text { alkaline stress }\end{array}$ & $\begin{array}{l}\text { miRNA targeted genes (Lus-miRNAs) Myb domain protein, Mitochondrial } \\
\text { transcription termination factor family protein, Transcription regulators, } \\
\text { Auxin signaling F-box, }\end{array}$ & $\begin{array}{l}\text { Yu et al., 2016; Yu et al., } \\
\text { 2014; Barvkar et al., 2013; } \\
\text { Younas and Barozai, } 2012\end{array}$ \\
\hline $\begin{array}{l}\text { Nutrient use } \\
\text { efficiency }\end{array}$ & miRNA targeted genes ubiquitin-conjugating enzyme E2 (UBE2) gene & $\begin{array}{l}\text { Melnikova et al., 2014, } \\
\text { 2015; Neutelings } \text { et al., } 2012\end{array}$ \\
\hline $\begin{array}{l}\text { Pathogen } \\
\text { resistance }\end{array}$ & $\begin{array}{l}\text { Genes encoding cysteine proteases known to play an important role in pro- } \\
\text { grammed cell death (PCD) associated with the hypersensitive response } \\
\text { (HR), genes (c7149 and c } 48400 \text { ) encoding germin-like proteins potentially } \\
\text { associated with ROS production and cell-wall cross-linking in defense, gene } \\
\text { (Nbi-D c37826) involved in flax resistance to rust (Melampsora lini) }\end{array}$ & $\begin{array}{l}\text { Fenart et al., 2010; Lorenc- } \\
\text { Kukula et al., } 2007\end{array}$ \\
\hline $\begin{array}{l}\text { Transgenic } \\
\text { flax for agro- } \\
\text { nomic and } \\
\text { quality traits }\end{array}$ & $\begin{array}{l}\text { Genes encoding chalcone synthase, chalcone isomerase and dihydroflavonol } \\
\text { reductase; SsGT1 gene, higher resistance to Fusarium infection and signifi- } \\
\text { cant increase of the flavonoid glycoside content; high oleic flax through } \\
\text { RNAi-mediated multiple FAD2 gene silencing }\end{array}$ & $\begin{array}{l}\text { Lorenc-Kukuła et al., 2005; } \\
\text { 2009; Chen et al., 2015; } \\
\text { Ludvíková et al., 2015; } \\
\text { Soto-Cerda et al., } 2014\end{array}$ \\
\hline
\end{tabular}

affects India where flax is extensively cultivated in rain-fed conditions in central India. Despite recent advances in research on drought stress in a number of important crops such as wheat, rice and mustard, related progress in linseed is very limited, except few studies such as genome-wide analysis of drought induced gene expression (Dash et al., 2014) addressing the response of flax to drought at the molecular level. A major effect of climate change will be to alter the intensity as well as incidence of linseed diseases. There are germplasm sources with tolerance/resistance to biotic factors that could be incorporated into the cultivars through developmental breeding or germplasm enhancement. For the same purpose the genetics of several disease resistance traits have been investigated in linseed, and associated genes have been assigned (Keijzer and Metz, 1992; Kutuzova, 1998). Wild germplasm-pathogen systems have generally been ignored by plant pathologists; only a limited number of wild germplasm-pathogen systems (wild populations of Linum marginale and flax rust (Melamspora lini) have been extensively studied (Burdon and Leather, 1990). Considerable variability for resistance has been recognized in coevolved systems of wild germplasm and their pathogens. Knowledge of diseases and pathogens of wild germplasm allows construction of maps of geographic patterns of disease resistance that can facilitate more effective collection of resistant germplasm. Areas with a rich diversity of pathogens and a corresponding diversity of resistant plants ("pathogen parks") are excellent sites for in situ studies of diseases and pathogens of wild crop relatives. Analysis of agro-morphological diversity and oil content in Indian linseed germplasm resulted in identification of promising donors for oil content, early flowering and early maturity (Dikshit and Sivaraj, 2015). Genetic diversity study in indigenous and exotic linseed germplasm (Abdul Nizar and Mulani, 2015) led to identification of exotic as well as indigenous trait specific promising accessions for taller stalk, high seed yield, high oil content, more capsules per plant and earliness. However, despite great potential for the unknown future threats and wide recognition, the use of germplasm in breeding programs is still limited due to breeder's reluctance to use germplasm largely due to non-availability of reliable information economically important traits and fear of linkage drag (Upadhyaya et al., 2011). Therefore, to enhance utilization of germplasm, core collection and pre-breeding concepts were introduced recently. The main purpose of the core fraction a subset of accessions (5-10\% of the base collection) is to provide efficient access to the whole collection with minimum repetitiveness and widest range of variability useful for breeders or other users. Pre-breeding is the early phase of breeding utilizing germplasm. The end product of pre-breeding is although deficient in certain desirable characters but useful to plant breeders due to greater potential for direct utilization in a breeding programme than the original unadapted exotic sources. Prior to the conception of the core collection concept, a "genetic collection" of flax was established during the 1970 s at the N.I. Vavi- 
lov Institute in St. Petersburg, which includes about 250 lines with genetically defined morphological, agronomic or disease-resistance characters (Brutch, 2002). A catalogue listing 50 accessions as donors for specific genes controlling traits, such as resistance to rust, wilt, anthracnose, and pasmo, fibre content and quality, lodging resistance, earliness, seed oil content, seed size and capsule indehiscence, was published by the Vavilov Institute (Kutuzova, 2000). The Centre for Genetic Resources at Wageningen in The Netherlands has established a flax core collection of 84 accessions from 506 fibre flax accessions (van Soest and Bas, 2002).This core subset was used in evaluations for fibre characters (Booth et al., 2004). A core collection comprising of 381 accessions from the flax world collection of 3378 accessions maintained by Plant Gene Resources of Canada (PGRC) was also assembled recently (Diederichsen et al., 2013).

Linseed tailored to specific environments through the development of genomic tools: Anthropogenic climate changes viz. rising global temperature, scarce water availability, increased salinity, as well as changes in disease and pest prevalence pose a serious threat to food security due to direct impacts on crop production. Ever rising global population, fast diminishing natural resources coupled with declining soil fertility further complicate these already complex issues. Western Canada and parts of Russia are important linseed or fibre flax production regions, and, during the past century, average temperatures have increased, annual precipitation became less evenly distributed with a trend to more heavy precipitation events in these areas (Gitay et al., 2002). As germplasm (landraces and wild material in the wider Linum gene pool) is reservoir of beneficial alleles required for crop improvement, efficient quantification and utilization of these resources are underway through the continued development and implementation of strategies, for instance more powerful genetic tools and genomic information. In recent years, different molecular markers have been used to measure genetic variation and relationships in cultivars and landraces of linseed. The molecular characterization of Linum by Fu (2005) employed random amplified polymorphic DNA (RAPD) to examine a flax world collection of 2,727 germplasm accessions, while Cloutier and co-workers (2009, 2011, and 2012) employed simple sequence repeats (SSR) for mapping of QTLs underlying fatty acid composition traits. Fortunately, detailed study of diversity and further understanding of transcriptional level molecular mechanisms of flax adaptation to stress (Table 1) has been greatly accelerated by recent release of the flax genome sequence (Wang et al., 2012). Genomic regions underlying agronomic traits in linseed (Linum usitatissimum L.) were revealed very recently in 407 globally distributed flax accessions by association mapping using 448 microsatellite markers (Soto-Cerda et al.,
2013 ; 2014). Digital gene expression for the identification of several differentially expressed genes and saline-alkaline tolerant miRNAs in flax (Lus-miRNAs) using over 2.7 million unique sRNAs mapped to the flax genome were reported for the first time (Yu et al., 2014; 2016). Dash et al. (2014) conducted microarray analysis to study transcriptome associated with induced drought in flax and identified 183 differentially expressed genes (DeGs). Using a combination of molecular techniques such as high-throughput genomewide molecular markers and next-generation sequencing technology instrumentation, mobilizing and tracking putatively advantageous target alleles, and mutant stocks to facilitate proof of gene function or phenotypic response are powerful tools (Ragupathy et al., 2011). For the identification of mutant alleles, approaches such as targeting induced local lesions in genomes (TILLING; Colbert et al., 2001) can be highly informative and exceptionally promising emerging alternatives. Sequence and epigenetic variation across the majority of the gene complement of linseed can thereby be revealed, catalogued and made accessible to the breeding community.

Looking to the future: Plant breeders are continuously challenged to develop flax cultivars adapted to changing environments and market needs which is further stimulated due to importance of the healthrelated properties of flax in human and animal nutrition. To ensure long term sustainability of flax production, the diverse germplasm stored in genebanks is essential for search of new traits relevant to changing environmental and socio-economic needs, as on-farm diversity has already mostly disappeared. Concerted breeding efforts involving distant and exotic germplasm, collected from main centers of diversity are required in view of narrow genetic base of the modern varieties. On the other hand, the enormous merits of the landraces coupled with the threat of genetic erosion indicate the importance of landraces and to plan future work of major priority. The potential contributions of L. bienne as wild progenitor of cultivated flax, presently rare in genebanks deserves more attention as a genetic resource for flax breeding. The International Treaty on Plant Genetic Resources for Food and Agriculture did not cover the genus Linum (Fowler, 2004), thus, it is important to ensure that countries conserving Linum diversity be made aware of the present status of conserved germplasm and coordination of future conservation activities. Intense prebreeding and priority in evaluation to major genes essentially unavailable in the cultivated gene pool for development of short duration and heat tolerant high yielding varieties of linseed particularly for paddy fallows, and for utera cultivation carry immense importance. Effective trait mining should be focused using statistical approaches like focused identification of germplasm strategy (FIGS) combining environmental 
and geographical data with trait information. Furthermore, the international initiative DIVSEEK (2016) established to unlock the potential of crop diversity stored in genebanks worldwide and make it available to all to promote effective utilization of genetic variation in plant improvement, enhanced agricultural productivity, and sustainability ensures intelligent use of genetic diversity across the globe.

\section{Conclusion}

Linseed is predominantly grown under rain-fed (63\%), utera $(25 \%)$ and input starved conditions in India, due to which the increase in yields of this crop has not been so considerable. Till date the major research work carried out by linseed breeders lies in the area of varietal development mainly for yield and disease resistance for different agro-ecological regions of the country. Since there is no major study on trait specific evaluation and utilization of linseed germplasm in Indian context, present review is intended to emphasize the importance of unlocking the potential of these genetic resources through evaluation of genebank material. Measurements of agro-morphological variation will be helpful in the selection of suitable parents for breeding programs, while knowing the population structure of crop genotypes from morphological and DNA markers will be helpful for association studies through linkage disequilibrium in populations for identifying particular alleles associated with a given phenotype. Genetic enhancement for seed yield, early duration for utera cultivation to avoid moisture constraint, quality traits assume importance for rain-fed linseed agriculture from the consideration of growth, equity and sustainability.

\section{REFERENCES}

Abdul Nizar, M. and Mulani, R.M. (2015). Genetic diversity in indigenous and exotic linseed germplasm (Linum usitatissimum L.) Electronic Journal of Plant Breeding, 6(3): 848-854

Allaby, R. G., Peterson, G. W., Andrew, D. M. and Fu, Y. B. (2005). Evidence of the domestication history of flax (Linum usitatissimum) from genetic diversity of the Sad2 locus. Theor. Appl. Genet., 112: 58-65

Barvkar, V. T., Pardeshi, V. C., Kale, S. M., Qiu, S. Q., Rollins, M., Datla, R., Gupta, V. S., Kadoo, N. Y. (2013). Genome-wide identification and characterization of microRNA genes and their targets in flax (Linum usitatissimum). Planta, 237(4):1149-61

Bassett, C. M., Rodriguez-Leyva, D. and Pierce, G. N. (2009). Experimental and clinical research findings on the cardiovascular benefits of consuming flaxseed. Appl. Physiol. Nutr. Metab., 34: 965-74

Booth, I., Harwood, R. J., Wyatt, J. L. and Grishanov, S. (2004). A comparative study of the characteristics of fibre-flax (Linum usitatissimum). Ind. Crops Prod., 20: 89-95

Brutch, N. B. (2002). The flax genetic resources collection held at the N.I. Vavilov Institute, Russian Federation.
In: Maggioni, L.M., Pavelek, M., van Soest, L. J. M., Lipman, E. (eds) Flax genetic resources in Europe. IPGRI, Maccarese Rome, Pp 61-65

Burdon, J. J. and Leather, S. R. (1990). Pests, Pathogens and Plant Communities. Oxford: Blackwell. Pp. 344

Chen, J., Wang, L. and Thompson, L. U. (2006). Flaxseed and its components reduce metastasis after surgical excision of solid human breast tumor in nude mice. Cancer Lett., 234 (2): 168-175

Chen, Y., Zhou, X. R., Zhang, Z. J., Dribnenki, P., Singh, S. and Green, A. (2015). Development of high oleic oil crop platform in flax through RNAi-mediated multiple FAD2 gene silencing. Plant Cell Reports, 34: 643-653

Cloutier, S., Miranda, E., Ward, K., Radovanovic, N., Reimer, E., Walichnowski, A., Datla, R., Rowland, G., Duguid, S. and Ragupathy, R. (2012). Simple sequence repeat marker development from bacterial artificial chromosome end sequences and expressed sequence tags of flax (Linum usitatissimum L.). Theor. Appl. Genet., 125: 685-694

Cloutier, S., Niu, Z., Datla, R. and Duguid, S. (2009) Development and analysis of EST-SSRs for flax (Linum usitatissimum L.). Theor. Appl. Genet., 119: 53-63

Cloutier, S., Ragupathy, R., Niu, Z. and Duguid, S. (2011) SSR-based linkage map of flax (Linum usitatissimum L.) and mapping of QTLs underlying fatty acid composition traits. Mol. Breed., 28: 437-451

Colbert, T., Till, B. J., Tompa, R., Reynolds, S., Steine, M. N., Yeung, A. T., McCallum, C. M., Comai, L. and Henikoff, S. (2001). High-throughput screening for induced point mutations. Plant Physiology, 126: 480 484

Cullis, C. (2011). Linum. In: Wild Crop Relatives: Genomic and Breeding Resources Oilseeds. Kole C, (ed.) Springer, New York. pp 177-189

Dash, P. K., Cao, Y., Jailani, A. K., Gupta, P., Venglat, P., Xiang, D., Rai, R, Sharma, R., Thirunavukkarasu, N., Abdin, M. Z., Yadava, D. K., Singh, N. K., Singh, J., Selvaraj, G. Deyholos, M., Kumar, P. A. and Datla R. (2014). Genome-wide analysis of drought induced gene expression changes in flax (Linum usitatissimum) $G M$ Crops \& Food, 5(2): 106-119

Diederichsen, A. (2007) Ex-situ collections of cultivated flax (Linum usitatissimum L.) and other species of the genus Linum L. Genet. Resour. Crop Evol., 54: 661-678

Diederichsen, A. and Fu, Y.B. (2008). Flax genetic diversity as the raw material for future success. In: Proceedings of the international conference on flax and other bast plants, Saskatoon, Canada, Pp. 270-280

Diederichsen, A. and Ulrich, A. (2009). Variability in stem fibre content and its association with other characteristics in 1177 flax (Linum usitatissimum L.) genebank accessions. Ind. Crop Prod., 30(1): 33-39

Diederichsen, A., Kusters, P. M., Kessler, D., Bainas, Z. and Gugel, R. K. (2013). Assembling a core collection from the flax world collection maintained by Plant Gene Resources of Canada. Genet. Resour. Crop Evol., 60: 1479-1485

Diederichsen, A., Raney, J. P. and Duguid, S. D. (2006). Variation of mucilage in flax seed and its relationship with other seed characters. Crop Sci., 46: 365-371

Diederichsen, A., Rozhmina, T. A., Zhuchenko, A. A. and Richards, K. W. (2006b). Screening for broad adaptation in 96 flax (Linum usitatissimum L.) accessions 
under dry and warm conditions in Canada and Russia. Plant Genet. Resour. Newsl., 146: 9-16

Dikshit, N. and Sivaraj, N. (2015). Analysis of agromorphological diversity and oil content in Indian linseed germplasm. Grasas Aceites, 66(1): e060. doi: http://dx.doi.org/10.3989/gya.0689141

Dillman, A.C. (1953). Classification of flax varieties, 1946. USDA Technical Bulletin No. 1054. United States Department of Agriculture, Washington, DC, Pp 56.

DIVSEEK. (2016). DivSeek: harnessing crop diversity to feed the future. Retrieved August, 2016 from www.divseek.org/.

Dwivedi, C., Natarajan, K. and Matthees, D. P. (2005). Chemopreventive effects of dietary flaxseed oil on colon tumor development. Nutr. Cancer, 51(1): 52-58

El-Beltagi, H. S. (2008). Some biochemical markers for evaluation of flax cultivars under salt stress conditions. Nat. Fibers., 5(4): 316-30.

FAOSTAT. (2016) Production of Crops: Linseed: Area Harvested and Production (tonnes). Retrieved July, 2016 from http://faostat3.fao.org/ home/index.html

Fenart, S., Ndong, Y. A., Duarte, J., Rivière, N., Wilmer, J., van Wuytswinkel, O., Lucau, A., Cariou, E., Neutelings, G., Gutierrez, L., Chabbert, B., Guillot, X., Tavernier, R., Hawkins, S., and Thomasset, B. (2010). Development and validation of a flax (Linum usitatissimum L.) gene expression oligo microarray. BMC Genomics, 11: 592

Fowler, C. (2004). Accessing genetic resources: international law establishes multilateral system. Genet. Resour. Crop Evol., 51(6): 609-620

$\mathrm{Fu}, \mathrm{Y}$. B. (2005). Geographic patterns of RAPD variation in cultivated flax. Crop Sci., 45(3): 1084-1091

Fu, Y. B. (2011). Genetic evidence for early flax domestication with capsular dehiscence. Genet. Resour. Crop Evol., 58: 1119-1128

Gitay, H., Suarez, A. and Watson, R. T. (2002). Climate change and biodiversity: IPCC Technical Paper V. Intergovernmental Panel on Climate Change. Geneva. pp 77

Gorshkova, T., Gurjanov, O., Mikshina, P., Ibragimova, N., Mokshina, N., Salnikov, V., Ageeva, M., Amenitskii, S., Chernova, T. and Chemikosova, S. (2010). Specific type of secondary cell wall formed by plant fibers. Russian J. Plant Physiol., 57(3): 328-341

Green, A. G., Chen, Y., Singh, S. P., Dribnenki, J. C. P. (2008). Flax. In Compendium of transgenic crop plants. Kole $\mathrm{C}$ and Hall, T.C. (eds.) Oxford, Blackwell Publishing Ltd. Pp. 199-226

Gupta, U. S. (2007). Physiology of stressed crops. Georgia, USA, Science Publishers.

Heslop-Harrison, J. S. and Schwarzacher, T. (2012). Genetics and genomics of crop domestication. In: Altman, A. and Hasegawa, P. M. (eds.) Plant biotechnology and agriculture: Prospects for the 21st century. Elsevier Academic, USA, Pp. 3-18

Hosseinian, F. S., Rowland, G. G., Bhirud, P. R., Dych, J. H. and Tyler, R. T. (2004). Chemical composition and physicochemical and hydrogenation characteristics of high-palmitic acid solin (low linolenic acid flaxseed) oil. Journal of the American Oil Chemists' Society, 81: $185-188$

Huang, S. and Ziboh, A. (2001). Gamma-linolenic acid: Recent advances in biotechnology and clinical applica- tions. Champaign, IL, AOCS Press.

Keijzer, P. and Metz, P. L. (1992). Breeding of flax for fibre production in western Europe. In: Sharma H.S., van Sumere, C.F. (eds.) The biology and processing of flax. M. Publications, Belfast, Pp. 33-66

Kurt, O. and Bozkurt, D. (2006). Effect of temperature and photoperiod on seedling emergence of flax (Linum usitatissimum L.). Journal of Agronomy, 5: 541-545

Kutuzova, S. N. (1998). "Genetika l'na," [Genetics of flax], in Genetika kul'turnych rastenij (len, kartofel', morkov', zelennye kul'tury, gladiolus, jablona, ljucerna), [Genetics of cultivated plants (flax, potato, carrot, leafy vegetables, gladiolas, apple, alfalfa)], Dragavcev, V.A. and Fadeeva, T.S. (eds.), VIR, St. Petersburg, Pp. 6-52

Kutuzova, S. N. (2000). Katalog mirovoj kolekcii VIR, Vypusk 714, Donory chozjajstvenno cennych priznakov dja selekcii l'na-dolgunca. [Catalogue of the world collection at the VIR, Volume 714, donors of economically important characters for breeding of fibre flax]. VIR, St. Petersburg, Pp. 50

Lorenc-Kukuła, K., Amarowicz, R., Oszmiański, J., Doermann, P., Starzycki, M., Skała, J., Zuk, M., Kulma, A. and Szopa, J. (2005). Pleiotropic effect of phenolic compounds content increases in transgenic flax plant. Journal of Agricultural and Food Chemistry, 53: 3685-92

Lorenc-Kukula, K., Wróbel-Kwiatkowska, M., Starzycki, M. and Szopa, J. (2007). Engineering flax with increased flavonoid content and thus Fusarium resistance. Physiological and Plant Molecular Pathology, 70: 38-48

Lorenc-Kukuła, K., Zuk, M., Kulma, A., Czemplik, M., Kostyn, K., Skala, J., Starzycki, M. and Szopa, J. (2009). Engineering flax with the GT family 1 solanum sogarandinum glycosyl transferase SsGT1 confers increased resistance to Fusarium infection. Journal of Agricultural and Food Chemistry, 57: 6698-6705

Ludvíková, M. and Griga, M. (2015). Transgenic Flax/ Linseed (Linum usitatissimum L.) Expectations and Reality. Czech J. Genet. Plant Breed. 51 (4): 123-141

McHughen, A. (1987). Salt tolerance through increased vigor in a flax line (STS-II) selected for salt tolerance in vitro. Theor. Appl. Genet., 74: 727-32

Melnikova, L. N. V., Dmitriev, A. A., Belenikin, M. S., Speranskaya, A. S., Krinitsina, A. A., Rachinskaia, O. A., Lakunina, V. A., Krasnov, G. S., Snezhkina, A. V., Sadritdinova, A. F., Uroshlev, L. A., Koroban, N. V., Samatadze, T. E., Amosova, A. V., Zelenin, A. V., Muravenko, O. V., Bolsheva, N. L. and Kudryavtseva, A. V. (2015). Excess fertilizer responsive miRNAs revealed in Linum usitatissimum. Biochimie, 109: 36-41

Melnikova, N. V., Belenikin, M. S., Bolsheva, N. L., Dmitriev, A. A., Speranskaya, A. S., Krinitsina, A. A., Koroban, N. V., Samatadze, T. E., Amosova, A. V., Muravenko, O. V., Zelenin, A. V. and Kudryavtseva, A. V. (2014). Flax inorganic phosphate deficiency responsive miRNAs. Journal of Agricultural Science, 6(1): $156-160$

Neutelings, G., Fénart, S., Lucau-Danilaa, A. and Hawkins, S. (2012). Identification and characterization of miRNAs and their potential targets in flax. Journal of Plant Physiology, 169: 1754-1766

Ottai, M.E.S., Al-Kordy, M.A.A. and Afiah, S.A. (2011). Evaluation, correlation and path coefficient analysis among seed yield and its attributes of oil flax (Linum 
usitatissimum) Genotypes. Aust. J. Basic Appl. Sci., 5: 252-258

Ragupathy, R., Rathinavelu, R. and Cloutier, S. (2011). Physical mapping and BAC-end sequence analysis provide initial insights into the flax (Linum usitatissimum L.) genome. BMC Genomics, 12: 217

Rashid, K. Y. (2003). Principal diseases of flax. In Flax, the genus Linum, Muir, A. D. and Westcott, N. D. (eds.) Taylor \& Francis, London, UK. Pp. 92-123

Roach, M. and Deyholos, M. (2007). Microarray analysis of flax (Linum usitatissimum L.) stems identifies transcripts enriched in fibre bearing phloem tissues. Mol. Genet. Genom., 278: 149-165

Roach, M. and Deyholos, M. (2008). Microarray analysis of developing flax hypocotyls identifies novel transcripts correlated with specific stages of phloem fibre differentiation. Ann. Bot., 102(3): 317-330

Simopoulos, A. P. (2000). Human requirement for N-3 polyunsaturated fatty acids. Poult Sci., 79: 961-970

Simopoulos, A. P. (2002). The importance of the ratio of omega-6/ omega-3 essential fatty acids. Biomedicine and Pharmacotheraphy, 56: 365-379

Singh, J. (2004). Field evaluation of linseed, Linum usitatissimum L. germplasm for resistance to alteranaria and powdery mildew diseases. J. Oilseeds Res., 21: 208209

Soto-Cerda, B. J., Diederichsen, A., Ragupathy, R. and Cloutier, S. (2013). Genetic characterization of a core collection of flax (Linum usitatissimum L.) suitable for association mapping studies and evidence of divergent selection between fibre and linseed types. BMC Plant Biology, 13: 78

Soto-Cerda, B. J., Duguid, S., Booker, H., Rowland, G., Diederichsen, A. and Cloutier, S. (2014). Genomic regions underlying agronomic traits in linseed (Linum usitatissimum L.) as revealed by association mapping. $J$. Integr. Plant Biol., 56: 75-87

Upadhyaya, H. D., Thudi, M., Dronavali, N., Gujaria, N., Singh, S., Sharma, S. and Varshney, R. K. (2011). Genomic tools and germplasm diversity for chickpea improvement. Plant Genetic Resources, 9: 45-58 van Soest, L. J. M. and Bas, N. (2002). Current status of the CGNLinum collection. In: Maggioni, L. M., Pavelek, M., van Soest, L. J. M., Lipman, E. (eds.) Flax genetic resources in Europe. IPGRI, Maccarese Rome,Pp.44-48

Vavilov, N. I. (1951). The origin, variation, immunity and breeding of cultivated plants. Chronica Botanica, 13: 1-366.

Wang, L., Chen, J. and Thompson, L. U. (2005). The inhibitory effect of flaxseed on the growth and metastasis of estrogen receptor negative human breast cancer xenograftsis attributed to both its lignan and oil components. Int. J. Cancer, 116 (5): 793-798

Wang, Z., Hobson, N., Galindo, L., Zhu, S., Shi, D., McDill, J., Yang, L., Hawkins, S., Neutelings, G., Datla, R., Lambert, G., Galbraith, D. W., Grassa, C. J., Geraldes, A., Cronk, Q. C., Cullis, C., Dash, P. K., Kumar, P. A., Cloutier, S., Sharpe, A. G., Wong, G. K., Wang, J. and Deyholos, M. K. (2012). The genome of flax (Linum usitatissimum) assembled de novo from short shotgun sequence reads. Plant J., 72: 461-73

Westcott, N. A. and Muir, A. D. (2003). Flax seed lignan in disease prevention and health promotion. Phytochem. Rev., (2): 401-417

Younas, M. and Barozai, K. (2012). In silico identification of micro rnas and their targets in fiber and oil producing plant flax (Linum usitatissimum L.). Pakistan J. Bot., 44 (4): 1357-62

Yu, Y., Huang, W. G., Chen, H. Y., Wu, G. W., Yuan, H. M., Song, X. X., Kang, Q. H., Zhao, D. S., Jiang, W. D., Liu, Y., Wu, J. Z., Cheng, L. L., Yao, Y. B. and Guan, F. Z. (2014). Identification of differentially expressed genes in flax (Linum usitatissimum L.) under saline-alkaline stress by digital gene expression. Gene, 549(1): 113-22

Yu, Y., Wu, G., Yuan, H., Cheng, L., Zhao, D., Huang, W., Zhang, S., Zhang, L., Chen, H., Zhang, J. and Guan, F. (2016). Identification and characterization of miRNAs and targets in flax (Linum usitatissimum) under saline, alkaline, and saline-alkaline stresses. BMC Plant Biology, 16: 124

Zhuchenko, A. A. and Rozhmina, T. A. (2000). Mobilizacija genetičeskich resursov l'na [Mobilization of flax genetic resources], VILAR AND VNIIL, Starica. Pp. 224 